\title{
Towards ground-truthing of spaceborne estimates of above-ground life biomass and leaf area index in tropical rain forests
}

\author{
P. Köhler ${ }^{1}$ and A. Huth ${ }^{2}$ \\ ${ }^{1}$ Alfred Wegener Institute for Polar and Marine Research, P.O. Box 120161, 27515 Bremerhaven, Germany \\ ${ }^{2}$ UFZ - Helmholtz Centre for Environmental Research, Department of Ecological Modelling, Permoserstr. 15, \\ 04318 Leipzig, Germany
}

Received: 26 April 2010 - Published in Biogeosciences Discuss.: 5 May 2010

Revised: 4 August 2010 - Accepted: 13 August 2010 - Published: 25 August 2010

\begin{abstract}
The canopy height $h$ of forests is a key variable which can be obtained using air- or spaceborne remote sensing techniques such as radar interferometry or LIDAR. If new allometric relationships between canopy height and the biomass stored in the vegetation can be established this would offer the possibility for a global monitoring of the above-ground carbon content on land. In the absence of adequate field data we use simulation results of a tropical rain forest growth model to propose what degree of information might be generated from canopy height and thus to enable ground-truthing of potential future satellite observations. We here analyse the correlation between canopy height in a tropical rain forest with other structural characteristics, such as above-ground life biomass (AGB) (and thus carbon content of vegetation) and leaf area index (LAI) and identify how correlation and uncertainty vary for two different spatial scales. The process-based forest growth model FORMIND2.0 was applied to simulate (a) undisturbed forest growth and (b) a wide range of possible disturbance regimes typically for local tree logging conditions for a tropical rain forest site on Borneo (Sabah, Malaysia) in South-East Asia. In both undisturbed and disturbed forests AGB can be expressed as a power-law function of canopy height $h\left(\mathrm{AGB}=a \cdot h^{b}\right)$ with an $r^{2} \sim 60 \%$ if data are analysed in a spatial resolution of $20 \mathrm{~m} \times 20 \mathrm{~m}$ ( $0.04 \mathrm{ha}$, also called plot size). The correlation coefficient of the regression is becoming significant better in the disturbed forest sites $\left(r^{2}=91 \%\right)$ if data are analysed hectare wide. There seems to exist no functional dependency between LAI and canopy height, but there is also a linear correlation $\left(r^{2} \sim 60 \%\right)$ between AGB and the area fraction of
\end{abstract}

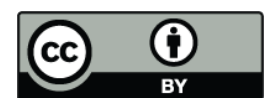

Correspondence to: P. Köhler (peter.koehler@awi.de) gaps in which the canopy is highly disturbed. A reasonable agreement of our results with observations is obtained from a comparison of the simulations with permanent sampling plot (PSP) data from the same region and with the large-scale forest inventory in Lambir. We conclude that the spaceborne remote sensing techniques such as LIDAR and radar interferometry have the potential to quantify the carbon contained in the vegetation, although this calculation contains due to the heterogeneity of the forest landscape structural uncertainties which restrict future applications to spatial averages of about one hectare in size. The uncertainties in AGB for a given canopy height are here $20-40 \%$ (95\% confidence level) corresponding to a standard deviation of less than $\pm 10 \%$. This uncertainty on the 1 ha-scale is much smaller than in the analysis of 0.04 ha-scale data. At this small scale (0.04 ha) AGB can only be calculated out of canopy height with an uncertainty which is at least of the magnitude of the signal itself due to the natural spatial heterogeneity of these forests.

\section{Introduction}

Tropical forests contain about $50 \%$ of the carbon stored in the vegetation worldwide (Sabine et al., 2004). Carbon emissions from tropical deforestation are with about 1.5 $\mathrm{Pg} \mathrm{C} \mathrm{yr}^{-1}$ (years 2000-2007) responsible for $16 \%$ of the total anthropogenic carbon emissions (Global-CarbonProject, 2008). The carbon flux from deforestation in SouthEast Asia was estimated in 2007 with $0.6 \mathrm{Pg} \mathrm{C} \mathrm{yr}^{-1}$ to be as large as that from Latin America (Canadell et al., 2007; Global-Carbon-Project, 2008). These carbon fluxes have estimated uncertainties of around $50 \%$ and they are within the global carbon cycle those which are by far the most uncertain

Published by Copernicus Publications on behalf of the European Geosciences Union. 
ones (Le Quéré et al., 2009). For balancing the global carbon budget in higher accuracy than today, also of interest for Reducing Emissions from Deforestation and Degradation (REDD) within the United Nations Framework Convention on Climate Change (UNFCCC), it is therefore necessary to reduce the uncertainties contained in the land-atmosphere carbon fluxes.

Our knowledge of the amount of carbon stored in tropical forests is incomplete, but steadily increasing. From tree allometry it is now known that above-ground life biomass AGB (and thus carbon contained in the vegetation) might be calculated best out of trunk diameter or basal area of trees (Chave et al., 2005; Slik et al., 2010). Other variables, such as wood density, are of minor importance (Chave et al., 2005). However, allometric relations between the integrating variables canopy height and standing above-ground life biomass for tropical rain forests are so far missing. Biomass estimates and changes in carbon allocation were calculated from ground measurements for various different areas (e.g. Chave et al., 2003, 2008; Aragão et al., 2009; Lewis et al., 2009; Slik et al., 2010). These estimates are restricted to selected research plots and a spatially complete coverage is still lacking.

To overcome the uncertainty in our knowledge of carbon stored in vegetation and to monitor future changes spaceborne remote sensing techniques such as LIDAR or radar interferometry seems to be one of the possible solutions. Various studies used remote sensing for forest characterisation (e.g. Garrigues et al., 2008; Anderson et al., 2009; Bergen et al., 2009; Potter et al., 2009; Frolking et al., 2009; Hawbaker et al., 2009; Dubayah et al., 2010) and first approaches to extend the plot data on AGB to larger regions exist for the Amazon (e.g. Malhi et al., 2006; Saatchi et al., 2007). For a temperate forest a combination of optical remote sensing to provide the vegetation type together with LIDAR provides even better estimates of AGB than LIDAR alone (NiMeister et al., 2010). The lack of data especially for tropical forests in Africa and South-East Asia might be improved by future satellite mission for spaceborne remote sensing of the environment which are now underway (e.g. TANDEML or DESDynI (http://desdyni.jpl.nasa.gov) (Frolking et al., 2009; Moreira et al., 2009; Hurtt et al., 2010)). These missions plan to make frequent remeasuring of standing vegetation feasible. Interpretation of the spaceborne data on land carbon stocks is needed, not only from the scientific point of view, but also within practical carbon management options mentioned in UNFCCC and REDD. Houghton et al. (2009) laid out the required specifications for these and other future satellite missions to significantly reduce the nowadays existing uncertainties. They claimed, that in order to reduce the uncertainty in the land-atmosphere fluxes to those of the next uncertain term (which is the net carbon uptake of the ocean with an uncertainty of $\pm 18 \%$ ) a measurement error of less than $2 \mathrm{MgC}$ (or an AGB uncertainty of about 4 tons organic dry matter, abbreviated $t$ in the following) per ha over
$25 \mathrm{ha}$ is required. It is furthermore argued, that deforestation is patchy on spatial scales of $100 \mathrm{~m}$ and less and only if remote sensing is operating on a similar scale, one can clearly identify changes in carbon storage over time and minimise sampling errors due to averaging.

One crucial aspect of remote sensing estimates of vegetation parameters, however, is the validation against reference measurements, so-called ground-truthing. Remote sensing by LIDAR or radar interferometry nowadays accurately describes, for example, the height of the canopy in various different forest types in temperate and tropical regions (e.g. Lefsky et al., 2002, 2005; Balzter et al., 2007; Hajnsek et al., 2009). To be able to calculate other parameters of the forest (e.g. carbon content) out of the canopy height some well justified assumptions need to be made. In other words some new or modified allometric relationships between canopy height and other structural parameters need to be established. It would therefore be of interest to compare forest inventory data of plots of similar size as the footprint of the satellite with results from remote sensing techniques. This attempt is especially difficult in tropical forest with only about ten globally distributed large research plots of 50 ha in size (Condit, 1995), although the amount and distribution of field sites was significantly increased during the last years, e.g. in the Amazon (Malhi et al., 2006) or on Borneo (Slik et al., 2009, 2010).

The attempt of this study is to use in the light of restricted field inventories in the tropics the results of a process-based tropical forest growth model to analyse allometric relationships between canopy height $h$, a major forest variable measurable from spaceborne remote sensing techniques such as LIDAR and radar interferometry, and of AGB and leaf area index (LAI), both variables of interest in the research of the carbon cycle and of vegetation dynamics. Accuracy and uncertainties in the calculation of the canopy height during remote sensing are not discussed in detail here, but see Hajnsek et al. (2009). We show from simulations covering the range of disturbances typically found in tropical rain forests in Borneo, how accurate AGB (and thus the carbon content of the vegetation) and LAI can be determined, once the canopy height is known. One specific objective is to investigate how the accuracy of the correlation of these variables alters if data are analysed on different spatial scales. The analysis is therefore performed on (i) a forest plot level of $20 \mathrm{~m} \times 20 \mathrm{~m}$ ( $0.04 \mathrm{ha})$, representative of the crown size of emergent trees in the study area and of the achievable spatial resolution of spaceborne remote sensing configurations (Frolking et al., 2009), and (ii) for larger areas of one hectare ( $1 \mathrm{ha}$ ). The ha-wide averages furthermore enable us to calculate relationships between the degree of canopy disturbance and AGB. Simulation results are finally compared with field data from disturbed and undisturbed forests in Borneo. Our analysis should be understood as a case study for a typical tropical rain forest site in South-East Asia and should highlight which degree of information on AGB and LAI might be 
achieved from remote sensing techniques using LIDAR and radar interferometry. While results would certainly differ in detail for other tropical forest sites, the general intrinsic uncertainty of biomass calculations based on canopy height and the role of the spatial scale of the remote sensing approach highlighted here are of general importance.

\section{Methods}

\subsection{Description of the model}

We used the individual-oriented process-based forest growth model FORMIND (Köhler and Huth, 1998) in its updated version FORMIND2.0 (Köhler, 2000) to simulate the forest dynamics of an uneven-aged mixed tropical rain forest. The model has been proven suitable to simulate a wide range of forest sites on Borneo (Sabah) (Köhler et al., 2001), Venezuela (Kammesheidt et al., 2001), French Guiana (Köhler et al., 2003), Mexico (Rüger et al., 2008), Brazil (Groeneveld et al., 2009) and Ecuador (Dislich et al., 2009). The site-specific model adaptation and parametrisation to a dipterocarp tropical rain forest in Borneo (Sabah) as used here were published elsewhere (Huth et al., 2004, 2005; Köhler and Huth, 2004). Here, the model is used in exactly the same configuration as in these three applications. The model was also used in an extended version for the analysis of tree species richness in Sabah depending on disturbance and recruitment limitation (Köhler and Huth, 2007).

The model describes forest dynamics as a mosaic of interacting forest patches. These patches have the same spatial dimensions as the typical crown size of emergent trees in our observation area $(20 \mathrm{~m} \times 20 \mathrm{~m})$. This also implies that the spatial resolution possible with FORMIND2.0 is similar to that of remote sensing estimates (Frolking et al., 2009; Hajnsek et al., 2009). Finer spatial-scale features are not covered by the model. Within these patches trees are not spatially explicitly distributed, and thus all compete for light and space following the gap model approach (Botkin, 1993). Allometric relationships connect the above-ground life biomass of a tree with its stem diameter, the tree height, the bole volume and the crown dimensions. Using these relationships, the distribution of individual tree crowns and their leaf area in the canopy is calculated in horizontal canopy layers with a discretisation of $0.5 \mathrm{~m}$. The model operates with the conceptual time step of one year.

The growth of an individual tree is based on a carbon balance. Calculations include the photosynthesis of the trees and assimilate losses due to respiration, litter-fall and fine root decay. Within a patch, vertical light attenuation in the canopy is calculated from light intensity above the canopy with respect to the absorption of tree crowns. The dependence of specific photosynthetic productivity on irradiance is modelled using a Michaelis-Menten-type light response curve. Photosynthetic production is calculated from the tree's leaf area. We assume an increasing limitation effect of water transport deficiencies with increasing tree height. Thus, actual productivity is calculated by applying a sizedependent limitation factor. Assimilation losses are estimated in relation to tree biomass. We distinguish between biomass-dependent maintenance respiration and growth respiration. Tree growth is calculated in annual time steps. Competition is modelled in terms of competition for light and space, the latter resulting in self-thinning. Mortality is modelled as a stochastic event. Trees die with a certain groupspecific probability. Of all dying trees $40 \%$ collapse and knock down smaller trees in neighbouring patches and create gaps of a size depending upon their crown size. Recruitment takes into account the production and explicit dispersal of individual seeds produced by local mother trees. We assume constant seed input rates which is correlated with the reproductive success at minimum diameter of $1 \mathrm{~cm}$. Thus, the seed production rate lumps together several regeneration stages: fecundity, seed survival, germination and possible predation upon young seedlings. Incoming seeds update a seed pool, taking into account the dormancy variability across functional groups.

We took an undisturbed, primary forest stand (P1) for our stand initialisation from a research inventory in the Deramakot Forest Reserve (DFR) in Sabah (North Borneo, Malaysia, $117^{\circ} 30^{\prime} \mathrm{E}, 5^{\circ} 25^{\prime} \mathrm{N}, 130-300 \mathrm{~m}$ a.s.l.) (Schlensog, 1997). Deramakot has a per-humid climate typical of the inner tropics. The mean annual temperature is $27^{\circ} \mathrm{C}$ with little seasonal variation. The average annual precipitation is about $3500 \mathrm{~mm}$, with no pronounced dry season. The geology of Deramakot is characterised by tertiary sediments, mostly sandstone. The soils are low in nutrients and prone to erosion once left devoid of tree cover. The prevailing forest type is lowland dipterocarp forest.

The shrub and tree species found in DFR (total number: 468 species) are assigned to 13 different plant functional types (PFT) based on their successional status and maximum height at maturity (Köhler et al., 2000). The successional status (early, mid, or late) is determined by their growth rates under various light regimes, as well as through a survey of wood densities, which are good indicators of growth rates for most species. In FORMIND2.0 thus the life-cycle of individual trees belonging to one of the 13 PFT is calculated.

\subsection{Simulated scenarios}

Besides the simulation of the evolution of the undisturbed dipterocarp forest (P1) for $400 \mathrm{yr}$ as reference case, we simulated a large number of typical logging scenarios for this region (in total 24 different scenarios, Table 1). The scenarios differ in the logging method responsible for the amount of damage caused in the residual forest stand, logging cycle (time period between two logging events), and cutting limit $d_{\text {min }}$ (only trees with a diameter above the cutting limit are logged). The size of the simulated forest area was kept 
Table 1. Simulation scenarios. Undisturbed site P1 or different logging scenarios with disturbed forests.

\begin{tabular}{lcccccccc}
\hline Scenario & $\begin{array}{c}\text { Logging } \\
\text { method }\end{array}$ & $\begin{array}{c}\text { Logging } \\
\text { cycle } \\
(\mathrm{yr})\end{array}$ & $\begin{array}{c}\text { Cutting } \\
\text { limit } \\
(\mathrm{cm})\end{array}$ & $\begin{array}{c}\text { Simulation } \\
\text { period } T \\
(\mathrm{yr})\end{array}$ & $\begin{array}{c}\text { Area } \\
A\end{array}$ & $\begin{array}{c}\text { Plots } \\
(\mathrm{ha})\end{array}$ & $\begin{array}{c}\text { runs } \\
\left(400 \mathrm{~m}^{2}\right)\end{array}$ & $\begin{array}{c}\text { tree } \\
\text { density } \\
(1 / \mathrm{ha})\end{array}$ \\
\hline P1 (undisturbed) & - & - & - & 400 & 100 & 2500 & 1 & 2795 \\
Logging (disturbed) & RIL, CON & $20,40,60,80$ & $40,50,60$ & 240 & 100 & 2500 & 24 & 3202 \\
\hline
\end{tabular}

constant at 100 ha and we assumed the boundary conditions to be periodic. The length of simulation in the logging scenarios was $240 \mathrm{yr}$.

Our modelling of logging methods was motivated by several studies, but see references and more details in Huth et al. (2004, 2005). We distinguish two methods: highly damaging conventional logging (CON), which generally uses heavy machinery and unskilled workers, but little planning, and reduced-impact logging (RIL), where substantial planning for road construction, felling directions etc. is performed. In RIL, tree removal usually implies the use of winching cables or airborne cable systems. The differences modelled between the two methods represent the logging impact on the residual stand. The time between two logging operations was constant, but differed between the scenarios (20, $40,60,80$ years). All commercial trees of the mid- and latesuccessional species above the cutting limit $\left(d_{\min }=40,50\right.$, $60 \mathrm{~cm}$ ) were removed in a logging operation.

The simulated forests were analysed over the whole simulated area $A$ (in ha) over the whole simulation periods $T$ (in yr) with outputs produced every year including one initial output at $t=0 \mathrm{yr}$. Thus, we can rely for every simulation on $(T+1) \times A$ data sets of ha-wide mean averages and on $(T+1) \times A \times 25$ on detailed 0.04 ha plot-related information. These are 40100 (ha) and 1002500 (0.04 ha) data sets for the $400 \mathrm{yr}$ runs of undisturbed simulation P1. The $24 \mathrm{log}$ ging scenarios contain 578000 (ha) and 14460000 (0.04 ha) data sets. On average, the simulated undisturbed and disturbed forests contained 2795 and 3202 trees per hectare, respectively.

In the simulated forests we analysed at different spatial scales ( 0.04 or 1 ha) the relationship between (a) canopy height $h$ and AGB and (b) canopy height $h$ and LAI. Canopy height is defined as the height of largest tree on the plot scale ( 0.04 ha), and as the mean height of the largest trees of the 25 individual plots of each ha on the 1 ha-scale. Additionally, at the 1 ha-scale the relationship between the gap fraction and AGB is analysed. Gap fraction is here defined as the fraction of the simulated forest area with a canopy height $h$ below $25 \mathrm{~m}$.

\subsection{Permanent sampling plots data from Sabah and large-scale field inventory from Lambir}

The data from PSPs, with which we compared our simulation results, were collected in five different forest reserves in Sabah, Malaysia between 1973 and 1993. The data are described and analysed in Köhler et al. (2001). PSPs are between 1 and 11 ha large, contain more than 12000 trees, which were sampled between 9 and 20 years in intervals of 1 to 5 years. All plots were regrowing forests in which during their first inventory the last logging event was 8 to 45 years ago. The PSP data therefore cover forest regrowth 8 to 54 years after disturbance. The data consist of repeated measurements of diameter at breast height (dbh). AGB is calculated out of $\mathrm{dbh}$ with the allometric relationship and species grouping embedded in FORMIND2.0.

The large-scale ( $52 \mathrm{ha}$ ) field inventory at Lambir covers one initial sampling of biomass per 0.04 ha plot (Yamakura et al., 1996). This forest is believed to be largely undisturbed by anthropogenic activities and might therefore be a representative for an undisturbed rain forest site on Borneo. However, please note, that the parametrisation of our model was not optimised for Lambir (Sarawak, Borneo), and differences in detail are therefore expected. The Lambir data set is nevertheless the largest forest inventory in South-East Asia comparable to the undisturbed dipterocarp forest in DFR used for parametrisation and initialisation of our simulation. However, besides the biomass distribution data used here other raw data were not available to us.

\section{Results}

\subsection{Undisturbed tropical rain forest}

In the simulation of undisturbed tropical rain forest only natural gap creation by falling large trees occurs, neither anthropogenic tree extraction nor external disturbances, such as storms, are considered. These simulations are potential representations of forest development (potential natural vegetation dynamics) in the remote interior of Borneo.

If analysed on the forest plot level (0.04 ha) AGB can be predicted from canopy height $h$ using a power-law function $\mathrm{AGB}=\mathrm{a} \cdot h^{b}$ (Zianis and Mencuccini, 2004; Chave et al., 


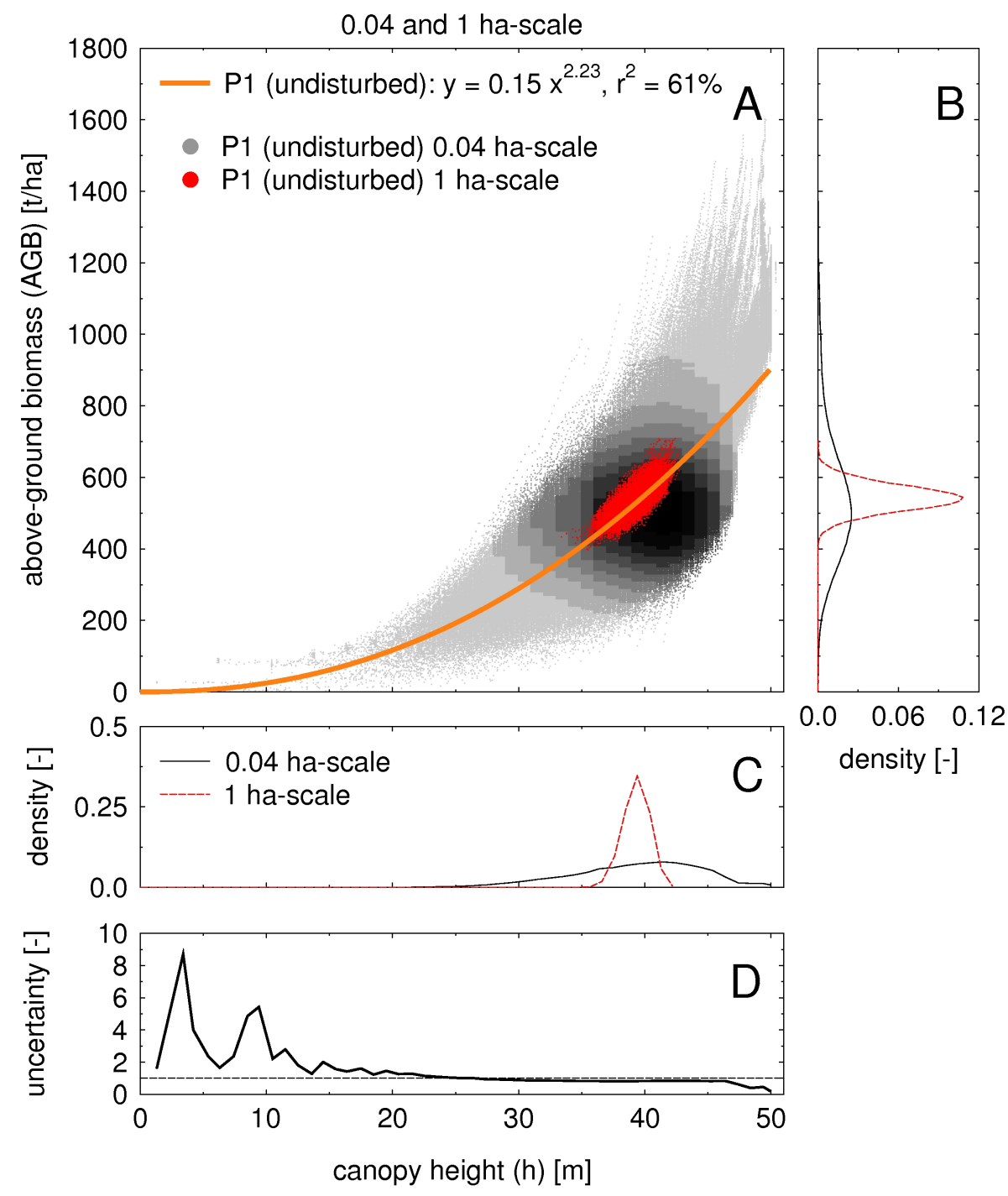

Fig. 1. Relation between above-ground life biomass (AGB) and canopy height $(h$ ) for the undisturbed forest (site P1). (A) Data on 0.04 hascale (grey to black) (red: 1 ha-scale for comparison) are plotted together with a power-law regression function. Due to the huge number of data points in the scatter plot of the 0.04 ha-scale (more than 1000000 ) the grey-scale indicates the density of the data points with highest densities in black. Normalised density of (B) AGB and of (C) $h$ for both spatial scales. Legend in C as in B. (D) Relative uncertainty (4 $\sigma /$ mean) of the $95 \%$ confidence interval, dotted horizontal line marks unity.

2005) with an $r^{2}=61.4 \%$ (Fig. 1a). Linear or quadratic function are with a correlation coefficient of $58.9 \%$ and $60.8 \%$, respectively, only slightly worse than the powerlaw equation. The frequency maxima in AGB and $h$ are at $485 \mathrm{t} / \mathrm{ha}$ and $41 \mathrm{~m}$, respectively (Fig. 1b, c). The spread in AGB data for a given canopy height is large. The relative uncertainty on the $95 \%$ confidence interval $(4 \sigma /$ mean) is larger than $100 \%$ for trees smaller than $26 \mathrm{~m}$ and generally larger than $200 \%$ for $h$ smaller than $12 \mathrm{~m}$ (Fig. 1d). The relative uncertainty is with $80-85 \%$ stable for canopy heights between 30 and $45 \mathrm{~m}$ and declines towards $20 \%$ for plots with canopy heights of $50 \mathrm{~m}$. The decline in relative uncertainty for canopies larger than $45 \mathrm{~m}$ might be caused by the low sample size. Only very few tree species, or PFTs, can grow to such heights, thus reducing the variability. To summarise, the variability of biomass growth underneath the largest growing tree within a plot is in tropical rain forests huge and a simple back calculation without additional information from canopy height to standing stock at this scale is ambiguous.

In the 1 ha-scale analysis regressions between AGB and $h$ are with $r^{2}=58 \%$ of similar quality than for the plot-size (0.04 ha-scale) (Fig. 2). However, uncertainties in the prediction of AGB as functions of $h$ are much smaller. Canopy height, now represented as ha-wide averages, varied only between 35 and $42 \mathrm{~m}$, the relative uncertainty was stable at $18-20 \%$ throughout the range of $h$ (95\% confidence level). 


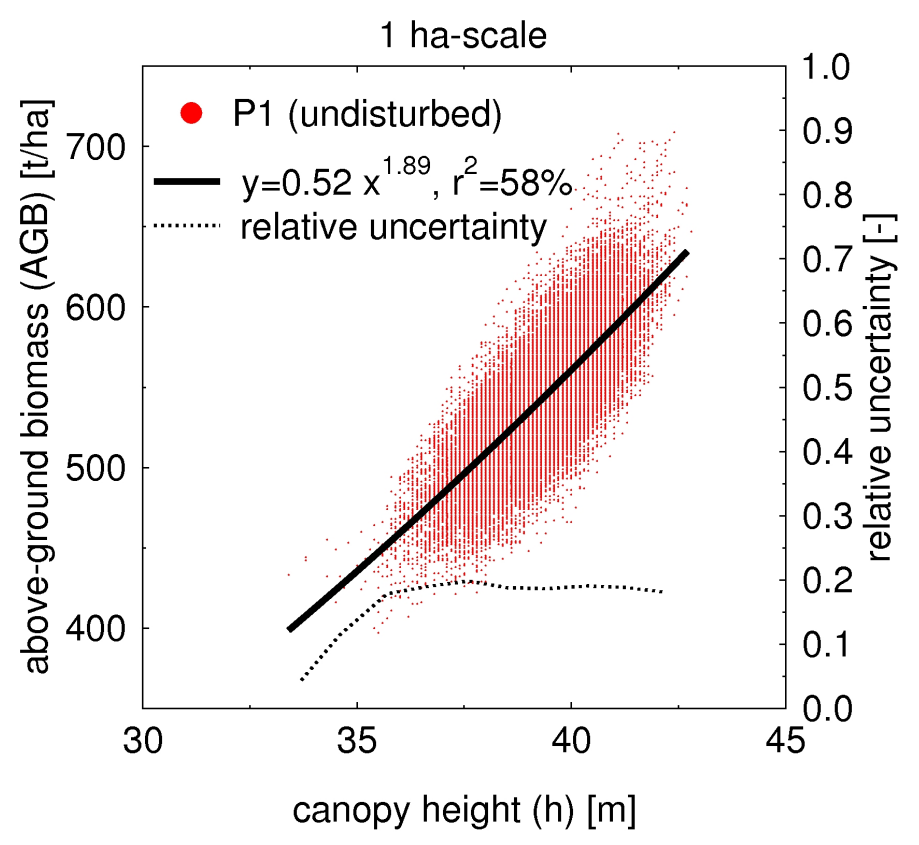

Fig. 2. Relation between above-ground life biomass (AGB) and canopy height $(h)$ in 1 ha-scale analysis for the undisturbed forest (site P1), including power-law regression function. Relative uncertainty ( $4 \sigma /$ mean) of the $95 \%$ confidence level plotted on right $y$-axis.

If compared with the plot level the frequency maxima are shifted towards higher AGB (545 t/ha) and smaller canopies $h(39 \mathrm{~m})$ (Fig. 1b, c).

As large-scale inventories of undisturbed forest sites are lacking in Sabah we restrict the comparison of simulation results to the large-scale inventory of the Lambir forest reserve in the Malaysian province Sarawak on Borneo. In the biomass distribution of the 1 ha-scale from the 52 ha inventory in Lambir (Yamakura et al., 1996) the frequency maxima of $541 \mathrm{t} / \mathrm{ha}$ is very close to $545 \mathrm{t} / \mathrm{ha}$ of our undisturbed forest simulations P1 (Fig. 3). The distribution is wider for Lambir in both spatial scales, probably due to the sampling size which was nearly three orders of magnitude smaller in the field data ( $n=40100$ or 52 ha for simulations and Lambir, respectively). This comparison is therefore restricted, but it shows that the biomass distribution of the simulated rain forest is within the range seen in real forest inventories, and strongly depends on the spatial scale.

\subsection{Logged (disturbed) tropical rain forest}

For the logged forests some interesting patterns emerged. The number of forest plots with large canopy heights is strongly reduced. The fraction of plots containing emergent trees with heights above $36 \mathrm{~m}$ is nearly halved (from $75 \%$ in undisturbed forests to $39 \%$ in logged forests). The maximum in the AGB distribution in the plot $(0.04 \mathrm{ha})$ scale is shifted from $500 \mathrm{t} / \mathrm{ha}$ in the undisturbed to $300 \mathrm{t} / \mathrm{ha}$ in the disturbed forests (Fig. 4b). Similarly, canopy height is reduced from a maximum in the distribution at $42 \mathrm{~m}$ to $37 \mathrm{~m}$ (Fig. 4c). In the PSPs the distribution is shifted to even smaller canopies (maximum at $\sim 30 \mathrm{~m}$ height) with less biomass (maximum $\sim 100 \mathrm{t} / \mathrm{ha}$ ). This indicates, that the PSP data do not cover the same range as the simulated disturbed forests, but are biased towards smaller, heavier disturbed sites. This bias is based on the fact, that the PSP data are restricted to 8-54 years after tree extraction. They are thus not representative for disturbed forest dynamics with long cutting cycles $(60$ 80 years), although these conditions are found in $50 \%$ of our logging scenarios.

On the 0.04 ha-scale regressions are with an $r^{2}$ of about $60 \%$ of similar quality for undisturbed and disturbed forests simulations as well as for the PSP data, although the powerlaw equations differ in detail (Fig. 4a, Table 2). The relative uncertainty on the $95 \%$ confidence level is slightly worse for the disturbed forests and the PSP data than for the undisturbed site P1, but both repeat the general pattern of the undisturbed forests (Fig. 4d).

On the larger spatial scale of ha-averages the power-law regression equation leads in the disturbed forest simulations as well as in the PSP data to significantly better agreement with the underlying data $\left(r^{2}=90\right.$ and $91 \%$, respectively) than in the undisturbed simulations (58\%) (Fig. 5a). One can clearly identify in the scatter plot of AGB over $h$ (Fig. 5a), that the undisturbed simulations are only a subsample at the upper end of the disturbed forest simulations. Furthermore, the PSP data represent the lower range of the disturbed forest simulations. The scatter of disturbed forest data points for AGB $<200 \mathrm{t} / \mathrm{ha}$ and canopy height $h \sim 32 \mathrm{~m}$ (Fig. 5a) is caused by the appearance of pioneer PFT after logging 

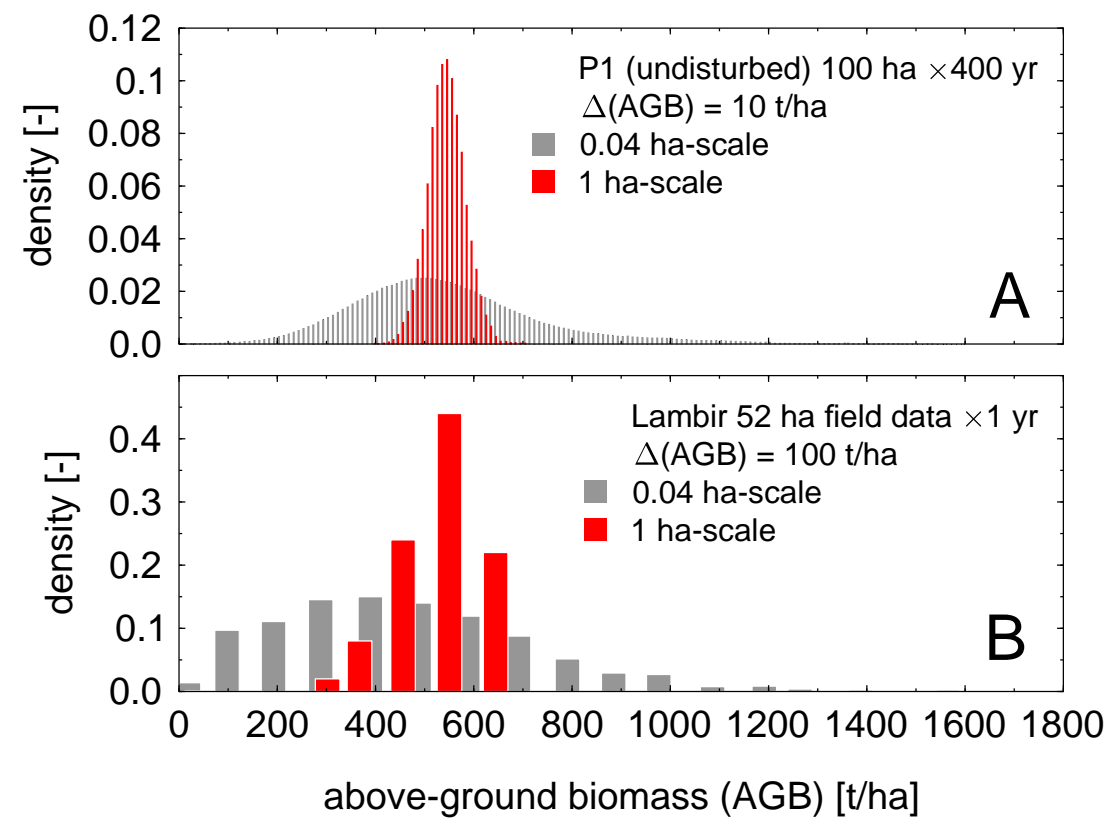

Fig. 3. Comparison of the normalised frequency distribution of above-ground life biomass for (A) undisturbed forests (site P1) with (B) field data from the large-scale inventory of 52 ha in Lambir, Sarawak, Malaysia (Yamakura et al., 1996) for both 0.04 and 1 ha-scale. P1 simulations were already plotted in Fig. 1b. P1 simulations cover 100 ha with annual output over $400 \mathrm{yr}(n=40100)$, while the Lambir field data cover one inventory over 52 ha $(n=52)$. The larger data ensemble of the simulations therefore enable a finer discretisation of AGB than the Lambir field data $(\Delta(\mathrm{AGB})=10$ and $100 \mathrm{t} / \mathrm{ha}$, respectively).

Table 2. Regression functions between above-ground life biomass (per plot or as ha-mean) and maximum height of trees or gap fraction (gap: maximum height of plot $<25 \mathrm{~m}$ ) of site for undisturbed site P1 or average over all 24 logging scenarios. All regressions are significant $(P<0.01)$.

\begin{tabular}{|c|c|c|c|c|c|c|c|}
\hline \multirow[b]{3}{*}{ Scenario } & \multirow{3}{*}{$\begin{array}{l}y: \\
x:\end{array}$} & \multicolumn{6}{|c|}{ Relation } \\
\hline & & \multicolumn{2}{|c|}{$\begin{array}{c}\mathrm{AGB}_{\text {plot }}(\mathrm{t} / \mathrm{ha}) \\
h(\mathrm{~m})\end{array}$} & \multicolumn{2}{|c|}{$\begin{array}{c}\mathrm{AGB}_{\mathrm{ha}}(\mathrm{t} / \mathrm{ha}) \\
\bar{h}(\mathrm{~m})\end{array}$} & \multicolumn{2}{|c|}{$\begin{array}{c}\mathrm{AGB}_{\mathrm{ha}}(\mathrm{t} / \mathrm{ha}) \\
\text { gap }(\%)\end{array}$} \\
\hline & & Function & $r^{2}$ & Function & $r^{2}$ & Function & $r^{2}$ \\
\hline P1 (undisturbed) & & $y=0.15 \cdot x^{2.23}$ & $61.4 \%$ & $y=0.52 \cdot x^{1.89}$ & $58.1 \%$ & $y=548-7.13 \cdot x$ & $1.7 \%$ \\
\hline Logging (disturbed) & & $y=0.44 \cdot x^{1.89}$ & $58.0 \%$ & $y=0.07 \cdot x^{2.42}$ & $90.6 \%$ & $y=394-4.95 \cdot x$ & $58.3 \%$ \\
\hline
\end{tabular}

operations. They dominate the plots for some years, before in the secondary successions other PFTs take over. However, because of their low wood densities these pioneers are rather unimportant for the calculation of mean aboveground life biomass. The relative uncertainty at the $95 \%$ confidence level is larger than $40 \%$ in the disturbed forests for canopies smaller than $25 \mathrm{~m}$, and between 20 and $40 \%$ for larger canopies and throughout the PSP data set (Fig. 5b).

There is no significant correlation between LAI and canopy height $\left(r^{2}<5 \%\right)$, neither in the undisturbed nor in the disturbed forest simulations, neither on the smaller 0.04 ha-scale (Fig. 6a) nor on the large 1 ha-scale (Fig. 6b). Again, PSP data are on the lower end of the range of the simulated data.
A linear relationship with an $r^{2}$ of $58 \%$ can be obtained from the 1 ha-scale analysis of AGB as function of gap fraction (Fig. 7a). Here, gaps are defined as $20 \mathrm{~m} \times 20 \mathrm{~m}$ plots with a canopy height below $25 \mathrm{~m}$. In all logging simulations there are areas with low gap fraction (typically $<15 \%$ ) and with high gap fraction (around 25\% for reduced-impact logging RIL, and above $40 \%$ for conventional logging CON), the range in-between is somehow not covered at all (Fig. 7b). This might be understood as the following: The high gap fractions are a direct result of the logging operations. Directly after logging the fast growing pioneer PFT grow first in these highly disturbed gap areas, and below them other trees species get established. Because logging disturbed the whole simulation area at the same time the closure of the forest canopy last as long as the growing of these pioneer trees 

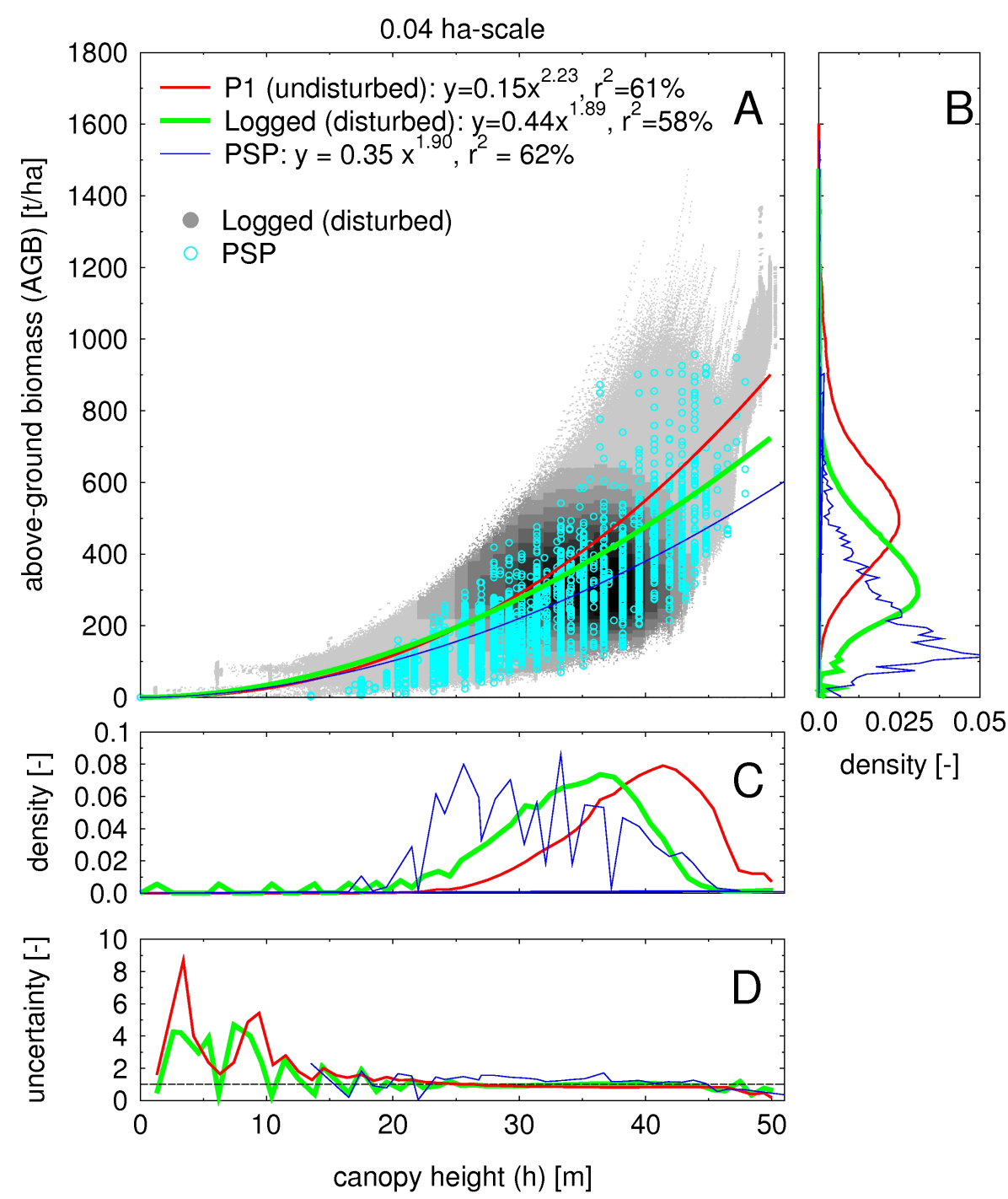

Fig. 4. Regression lines of above-ground life biomass (AGB) and canopy height $(h)$ in 0.04 ha-scale composition for the undisturbed forest (site P1), for disturbed forests (all 24 logging scenarios), and for permanent sampling plot data (PSP). The scatter plot of undisturbed (see Fig. 1) and disturbed forests are indistinguishable due to overlap and the data from the undisturbed site P1 are therefore omitted. Due to the huge number of data points in the scatter plot of the 0.04 ha-scale (more than 14000000 ) the grey-scale indicates the density of the data points with highest densities in black. Normalised density of (B) AGB and of (C) $h$ and relative uncertainty (D) on the $95 \%$ confidence level ( $4 \sigma /$ mean) are plotted for disturbed and undisturbed forest and PSP data, legend as on (A).

to $25 \mathrm{~m}$ height (threshold of the definition of a forest gap), and will thus happen more or less simultaneously in all plots which were disturbed by the logging operation. Each disturbance regime produces its own typical pattern in a AGB-gap fraction diagram (Fig. 7b). This is a first indication that such patterns might be detectable by remote sensing in the future to distinguish different disturbance regimes in tropical forests from air- and spaceborne observations.

\section{Discussion and conclusions}

To reduce the uncertainties in our knowledge of the carbon cycle a global coverage of the terrestrial carbon storage is a desirable target, for which spaceborne remote sensing techniques have to be applied. Repeated annual measurements could thus identify large sources and sinks of carbon due to large-scale deforestation or reforestation programs which might be performed within the framework of REDD.

Within this effort a knowledge of the uncertainties and at best their minimisation is crucial to determine whether or not new approaches might improve our knowledge of 

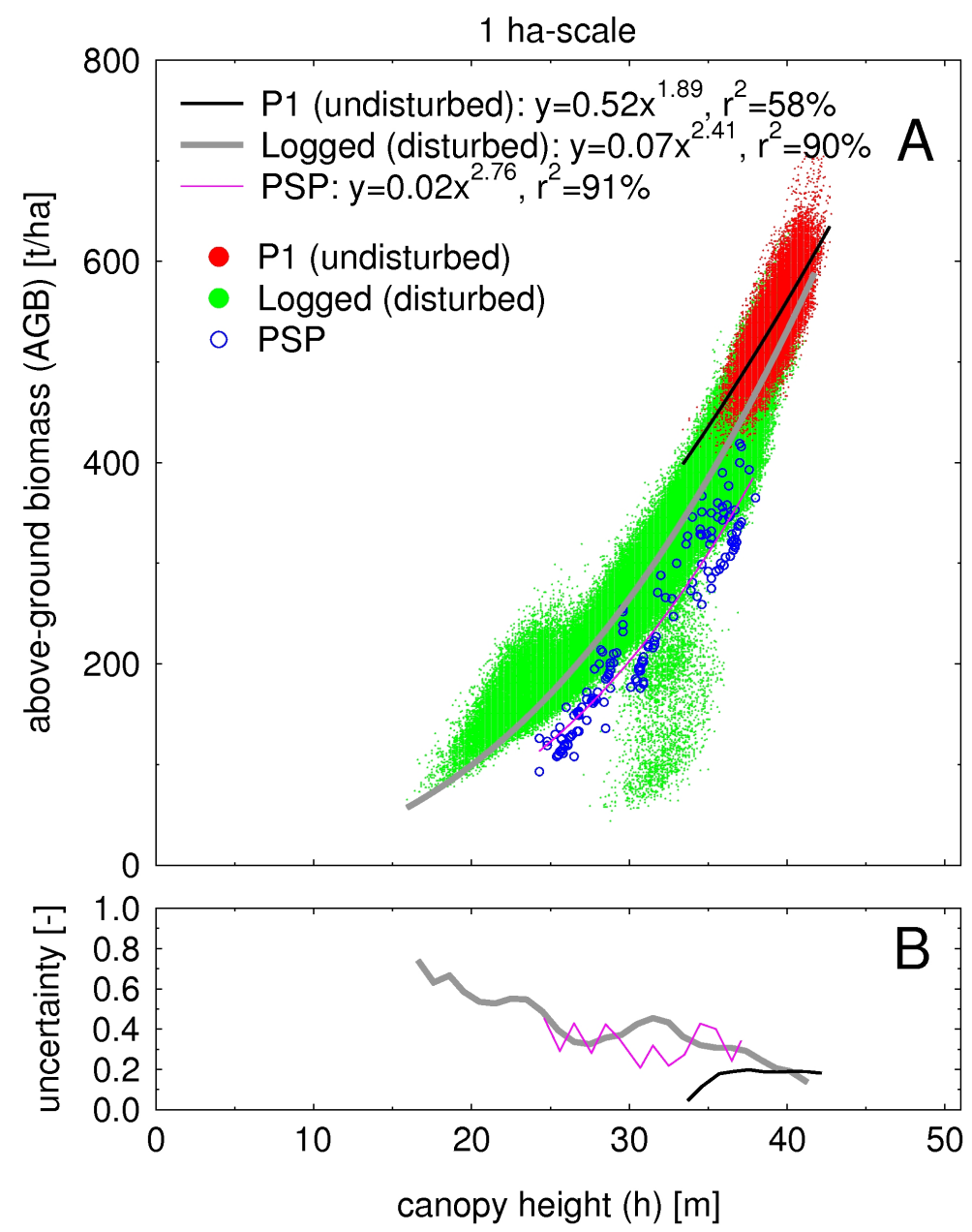

Fig. 5. (A) Above-ground life biomass (AGB) and canopy height $(h)$ in 1 ha-scale composition for the undisturbed site P1 (red), for disturbed forests in all 24 logging scenarios) (green), and for permanent sampling plot data (PSP, blue). (B) Relative uncertainty on the $95 \%$ confidence level ( $4 \sigma /$ mean), legend as in $(\mathrm{A})$.

the terrestrial carbon storage and its variability over time. It was already shown, how error propagates in inventorybased biomass estimates in tropical forests, in which AGB is typically derived from allometric relationship with the stem diameter of individual trees and only seldomly measured directly (Chave et al., 2004). Another huge uncertainty on the way to a complete carbon balance of tropical forests is the amount of carbon bound in dead wood, so-called necromass, above ground (Chao et al., 2009) and in forest soils below ground (Luyssaert et al., 2008). Both pools are largely unsampled, but might introduce due to their relatively small size in the tropics (Bonan, 2008) and due to their linear relationship with AGB only a small bias to the overall carbon budgets (Cairns et al., 1997).

If AGB is calculated not as a function of tree diameter known to be the best predictor of AGB (Chave et al., 2005; Slik et al., 2010), but from more aggregated variables such as canopy height, we implicitly pay for such an AGB estimate on the cost of precision. Remote sensing ap- proaches are one of the solutions for a large-scale systematic vegetation monitoring. There is a need to establish new allometric relationships for tropical forests. In the absence of field inventories covering all possible forest situations forest growth models are useful tools to derive such new relationships. This is especially the case for uneven-aged mixed forest stands in the tropics in which long logging cycles are necessary for sustainable timber harvesting. The simulation results can not completely compensate for inventories, but they can significantly broaden the spectra of possible forest situations on the plot level.

Another advantage of forest growth modelling is the consistency of the analysed set of simulation results. The FORMIND2.0-model does not account for uncertainties in the allometric relationships between dbh and AGB and reduces species-specific differences to the 13 PFT, which were selected for Borneo's rain forest. Thus, the uncertainties we here calculate are structural uncertainties between the aggregated variables canopy height $h$ and AGB and LAI. They 

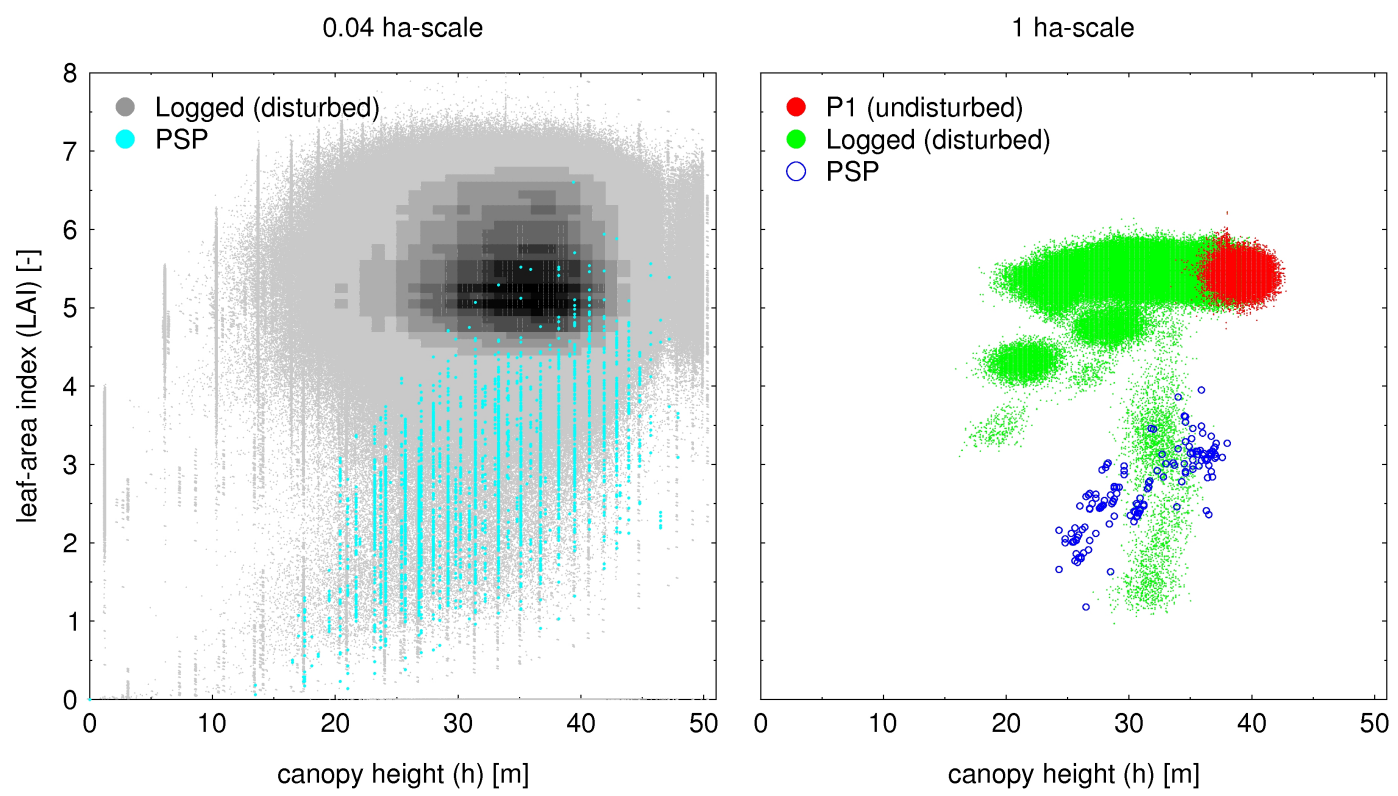

Fig. 6. Relation between leaf area index (LAI) and canopy height $(h)$. on the (A) 0.04 ha-scale and (B) 1 ha-scale. Results for the undisturbed site P1, for disturbed forests all 24 logging scenarios, and for permanent sampling plot data (PSP). In sub-figure (A) only disturbed (logged) forests and PSP data are shown, because the scatter plot for the undisturbed forest (P1) is indistinguishable from the disturbed forest data. Due to the huge number of data points in the scatter plot of the 0.04 ha-scale (more than 14000000 ) the grey-scale indicates the density of the data points with highest densities in black.
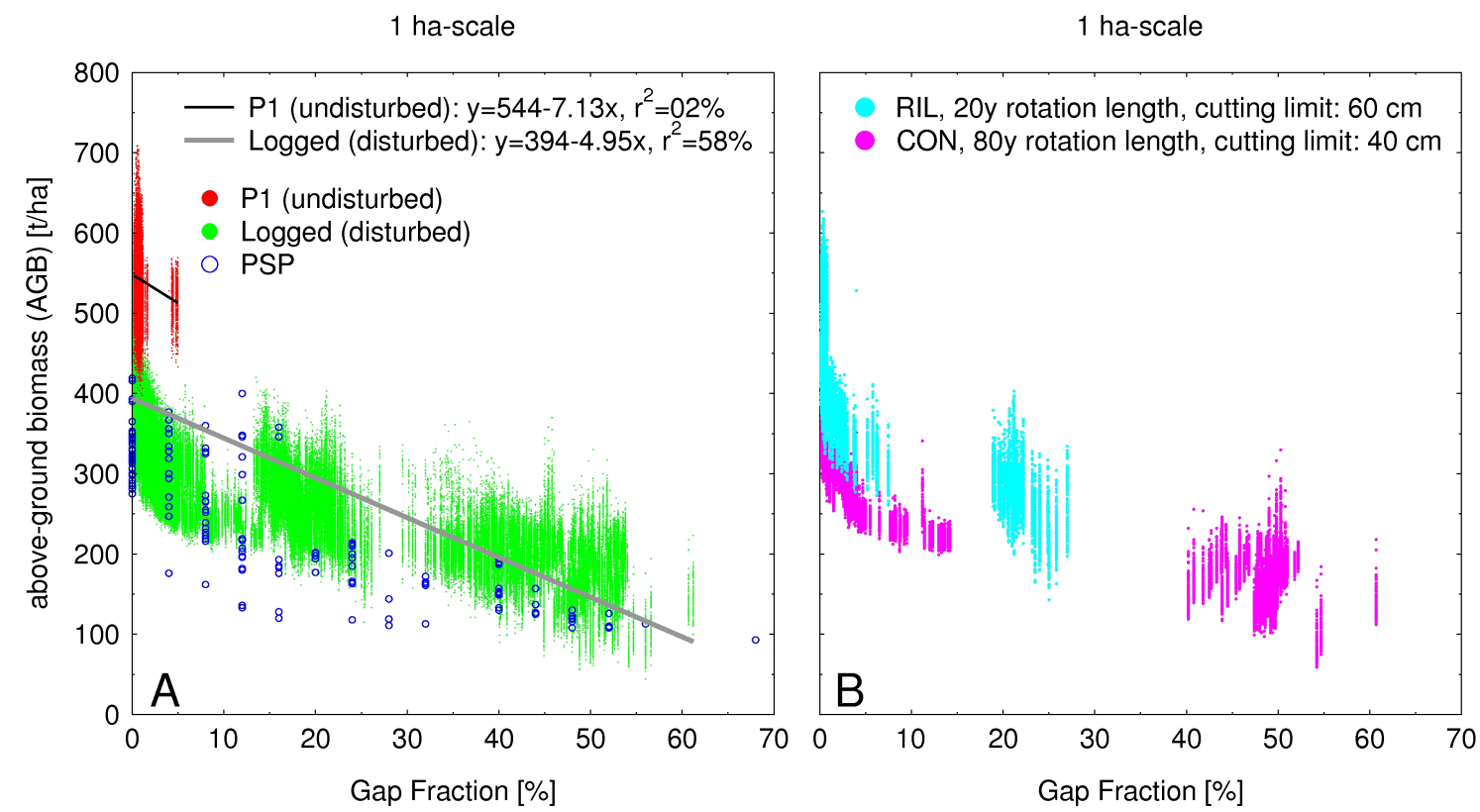

Fig. 7. Relation between above-ground life biomass (AGB) and gap fraction. Gaps are defined as individual $20 \mathrm{~m} \times 20 \mathrm{~m}$ plots with canopy height $h<25 \mathrm{~m}$. (A) Undisturbed forest P1 (red), disturbed forests of all logging scenarios (green), and permanent sampling plot data (PSP, blue). (B) Two specific examples for logging are highlighted: Cyan: reduced-impact logging, $80 \mathrm{y}$ return interval, minimal dbh of logged trees $=60 \mathrm{~cm}$. Magenta: conventional logging, $20 \mathrm{y}$ return interval, minimal dbh of logged trees $=40 \mathrm{~cm}$. 
might in detail differ in field inventories, but they are in principle contained in the vegetation structure of tropical rain forests.

We therefore conclude that the structural uncertainties in AGB estimates based on given spaceborne canopy height measurements are according to our simulations results (and in agreement with PSP data) on the order of $20-40 \%$ if hawide averages are investigated (95\% confidence level). However, for the calculation of the overall uncertainty of AGB the accuracy of the canopy height derived from remote sensing techniques must also be taken into consideration. Canopy height estimates obtained from airborne polarimetric interferometric synthetic aperture radar (Pol-InSAR) or airborne LIDAR over dipterocarp tropical rain forests have shown, that the mean canopy height of the hundred largest trees on one hectare can be measured with an accuracy of $10 \%(1 \sigma)$ (Hajnsek et al., 2009). It therefore seems possible that the suggested target of maximum uncertainty of $\pm 18 \%$ for AGB given by Houghton et al. (2009), equivalent to an uncertainty of $36 \%$ (95\% confidence level), can be reached. Our study shows that this would apply to tropical rain forest sites of nearly all disturbance regimes, if the aggregated information on the 1 ha-scale are used for the analysis. On the plot level (0.04 ha-scale) the uncertainties in AGB as a function of $h$ are as large as or larger than the signal itself. The uncertainty can be reduced if it would be possible to derive information on the vertical forest structure by remote sensing. According to our analysis the LAI can not be predicted from canopy height, but it should be emphasised that other approaches exist to estimate LAI directly with remote sensing techniques using optical and near-infrared sensors (e.g. Turner et al., 1999).

Acknowledgements. Parts of this project received fundings from ESA under the contract RFQ-3-11536/06/I-EC. We thank Kostas Papathanassiou, Florian Kugler and Astor Torano Caicoya for comments on earlier drafts.

Edited by: R. Duursma

\section{References}

Anderson, L. O., Malhi, Y., Ladle, R. J., Aragão, L. E. O. C., Shimabukuro, Y., Phillips, O. L., Baker, T., Costa, A. C. L., Espejo, J. S., Higuchi, N., Laurance, W. F., López-González, G., Monteagudo, A., Núñez-Vargas, P., Peacock, J., Quesada, C. A., and Almeida, S.: Influence of landscape heterogeneity on spatial patterns of wood productivity, wood specific density and above ground biomass in Amazonia, Biogeosciences, 6, 1883-1902, doi:10.5194/bg-6-1883-2009, 2009.

Aragão, L. E. O. C., Malhi, Y., Metcalfe, D. B., Silva-Espejo, J. E., Jiménez, E., Navarrete, D., Almeida, S., Costa, A. C. L., Salinas, N., Phillips, O. L., Anderson, L. O., Alvarez, E., Baker, T. R., Goncalvez, P. H., Huamán-Ovalle, J., Mamani-Solórzano, M., Meir, P., Monteagudo, A., Patiño, S., Peñuela, M. C., Prieto, A.,
Quesada, C. A., Rozas-Dávila, A., Rudas, A., Silva Jr., J. A., and Vásquez, R.: Above- and below-ground net primary productivity across ten Amazonian forests on contrasting soils, Biogeosciences, 6, 2759-2778, doi:10.5194/bg-6-2759-2009, 2009.

Balzter, H., Rowland, C., and Saich, P.: Forest canopy height and carbon estimation at Monks Wood National Nature Reserve, UK, using dual-wavelength SAR interferometry, Remote Sens. Environ., 108, 224-239, doi:10.1016/j.rse.2006.11.014, 2007.

Bergen, K. M., Goetz, S. J., Dubayah, R. O., Henebry, G. M., Hunsaker, C. T., Imhoff, M. L., Nelson, R. F., Parker, G. G., and Radeloff, V. C.: Remote sensing of vegetation 3-D structure for biodiversity and habitat: Review and implications for lidar and radar spaceborne missions, J. Geophys. Res., 114, G00E06, doi: doi:10.1029/2008JG000883, 2009.

Bonan, G. B.: Forest and climate change: forcgins, feedbacks, and the climate benefits of forests, Science, 320, 1444-1449, doi:10.1126/science.1155121, 2008.

Botkin, D. B.: Forest Dynamics: An Ecological Model, Oxford University Press, Oxford, 1993.

Cairns, M., Brown, S., Helmer, E., and Baumgardner, G.: Root biomass allocation in the world's upland forests, Oecologia, 111, 1-11, 1997.

Canadell, J. G., Le Quéré, C., Raupach, M. R., Field, C. B., Buitenhuis, E. T., Ciais, P., Conway, T. J., Gillett, N. P., Houghton, R. A., and Marland, G.: Contributions to accelerating atmospheric $\mathrm{CO}_{2}$ growth from economic acitivity, carbon intensity, and efficiency of natural sinks, P. Natl. A. Sci., 104, 1886618870, doi:10.1073/pnas.0702737104, 2007.

Chao, K.-J., Phillips, O. L., Baker, T. R., Peacock, J., LopezGonzalez, G., Vásquez Martnez, R., Monteagudo, A., and Torres-Lezama, A.: After trees die: quantities and determinants of necromass across Amazonia, Biogeosciences, 6, 1615-1626, doi:10.5194/bg-6-1615-2009, 2009.

Chave, J., Condit, R., Lao, S., Caspersen, J., Foster, R., and Hubbell, S.: Spatial and temporal variation in biomass of a tropical forest: results from a large census plot in Panama, J. Ecol., 91, 240-252, 2003.

Chave, J., Condit, R., Aguilar, S., Hernandez, A., Lao, S., and Perez, R.: Error propagation and scaling for tropical forest biomass estimates, Philos. T. Roy. Soc. B., 359, 409-420, doi: 10.1098/rstb.2003.1425, 2004.

Chave, J., Andalo, C., Brown, S., Cairns, M., Chambers, J., Eamus, D., Fölster, H., Fromard, F., Higuchi, N., Kira, T., Lescure, J.P., Nelson, B., Ogawa, H., Puig, H., Riéra, B., and Yamakura, T.: Tree allometry and improved estimation of carbon stocks and balance in tropical forests, Oecologia, 145, 87-99, doi:doi:10. 1007/s00442-005-0100-x, 2005.

Chave, J., Condit, R., Muller-Landau, H. C., T., S. C., Ashton, P. S., Bunyavejchewin, S., Co, L. L., Dattaraja, H. S., Davies, S. J., Esufali, S., Ewango, C. E. N., Feeley, K. J., Foster, R. B., Gunatilleke, N., Gunatilleke, S., Hall, P., Hart, T. B., Hernández, C., Hubbell, S. P., Itoh, A., Kiratiprayoon, S., LaFrankie, J. V., de Lao, S. L., Makana, J.-R., Nur Supardi Noor, M., Kassim, A. R., Samper, C., Sukumar, R., Suresh, H. S., Tan, S., Thompson, J., Tongco, M. D. C., Valencia, R., Vallejo, M., Villa, G., Yamakura, T., Zimmerman, J. K., and Losos, E. C.: Assessing evidence for a pervasive alteration in tropical tree communities, PLoS Biology, 6, e45, doi:10.1371/journal.pbio.0060045, 2008. Condit, R.: Research in large long-term tropical forest plots, Trends 
in Ecology and Evolution, 10, 18-21, 1995.

Dislich, C., Günter, S., Homeier, J., Schröder, B., and Huth, A.: Simulating forest dynamics of a tropical montane forest in South Ecuador, Erdkunde, 63, 347-364, doi:10.3112/erdkunde.2009. 04.05, 2009.

Dubayah, R. O., Sheldon, S. L., Clark, D. B., Hofton, M. A., Blair, J. B., Hurtt, G. C., and Chazdon, R. L.: Estimation of tropical forest height and biomass dynamics using lidar remote sensing at La Selva, Costa Rica, J. Geophys. Res., 115, G00E09, doi: 10.1029/2009JG000933, 2010.

Frolking, S., Palace, M. W., Clark, D. B., Chambers, J. Q., Shugart, H. H., and Hurtt, G. C.: Forest disturbance and recovery: A general review in the context of spaceborne remote sensing of impacts on aboveground biomass and canopy structure, J. Geophys. Res., 114, G00E02, doi:10.1029/2008JG000911, 2009.

Garrigues, S., Lacaze, R., Baret, F., Morisette, J. T., WQeiss, M., Nickeson, J. E., Fernandes, R., Plummer, S., Shabanov, N. V., Myneni, R. B., Knyazikhin, Y., and Yang, W.: Validation and intercomparison of global Leaf Area Index products derived from remote sensing data, J. Geophys. Res., 113, G02028, doi: 10.1029/2007JG000635, 2008.

Global-Carbon-Project: Carbon budget and trends 2007, (www. globalcarbonproject.org, last access: 26 September 2008), 2008.

Groeneveld, J., Alves, L., Bernacci, L., Catharino, E., Knogge, C., Metzger, J., Pütz, S., and Huth, A.: The impact of fragmentation and density regulation on forest succession in the Atlantic rain forest, Ecol. Model., 220, 2450-2459, doi:10.1016/j.ecolmodel. 2009.06.015, 2009.

Hajnsek, I., Kugler, F., Lee, S.-K., and Papathanassiou, K. P.: Tropical-Forest-Parameter Estimation by Means of Pol-InSAR: The INDREX-II Campaign, Ieee transactions on geoscience and remote sensing, 47, 481-493, doi:10.1109/TGRS.2008.2009437, 2009.

Hawbaker, T. J., Keuler, N. S., Lesak, A. A., Gobakken, T., Contrucci, K., and Radeloff, V. C.: Improved estimates of forest vegetation structure and biomass with a LiDARoptimized sampling design, J. Geophys. Res., 114, G00E04, doi:10.1029/2008JG000870, 2009.

Houghton, R. A., Hall, F., and Goetz, S. J.: Importance of biomass in the global carbon cycle, J. Geophys. Res., 114, G00E03, doi:10.1029/2009JG000935, 2009.

Hurtt, G. C., Fisk, J., Thomas, R. Q., Dubayah, R., Moorcroft, P. R., and Shugart, H. H.: Linking models and data on vegetation structure, J. Geophys. Res., 115, G00E10, doi:10.1029/2009JG000937, 2010.

Huth, A., Drechsler, M., and Köhler, P.: Multicriteria evaluation of simulated logging scenarios in a tropical rain forest, J. Environ. Manage., 71, 321-333, doi:10.1016/ j.envman.2004.03.008, 2004.

Huth, A., Drechsler, M., and Köhler, P.: Using multicriteria decision analysis and a forest growth model to assess impacts of tree harvesting in Dipterocarp lowland rain forests, Forest Ecol. Manage., 207, 251-232, doi:10.1016/j.foreco.2004.10.028, 2005.

Kammesheidt, L., Köhler, P., and Huth, A.: Sustainable timber harvesting in Venezuela: a modelling approach, J. Appl. Ecol., 38, 756-770, doi:10.1046/j.1365-2664.2001.00 629.x, 2001.

Köhler, P.: Modelling anthropogenic impacts on the growth of tropical rain forests - using an individual-oriented forest growth model for analyses of logging and fragmentation in three case studies, online at: http://hdl.handle.net/10013/epic.15101, last access: August 2010, PhD thesis, University of Kassel, Der Andere Verlag, Osnabrück, Germany, 2000.

Köhler, P. and Huth, A.: The effect of tree species grouping in tropical rain forest modelling - Simulation with the individual based model Formind, Ecol. Model., 109, 301-321, doi:10.1016/S0304-3800(98)00 066-0, 1998.

Köhler, P. and Huth, A.: Simulating growth dynamics in a SouthEast Asian rain forest threatened by recruitment shortage and tree harvesting, Climatic Change, 67, 95-117, doi:10.1007/s10584004-0713-9, 2004.

Köhler, P. and Huth, A.: Impacts of recruitment limitation and canopy disturbances on tropical tree species richness, Ecol. Model., 203, 511-517, doi:10.1016/j.ecolmodel.2006.11.023, 2007.

Köhler, P., Ditzer, T., and Huth, A.: Concepts for the aggregation of tropical tree species into functional types and the application on Sabah's lowland rain forests, species list used for the article at http://www.usf.uni-kassel.de/usf/archiv/ dokumente/specieslists/sabah/sabah.html, last access: August 2010, J. Trop. Ecol., 16, 591-602, 2000.

Köhler, P., Ditzer, T., Ong, R. C., and Huth, A.: Comparison of measured and modelled growth on permanent plots in Sabahs rain forests, Forest Ecol. Manage., 144, 101-111, doi:10.1016/S0378-1127(00)00364-9, 2001.

Köhler, P., Chave, J., Riéra, B., and Huth, A.: Simulating long-term response of tropical wet forests to fragmentation, Ecosystems, 6 , 129-143, doi:10.1007/s10021-002-0121-9., 2003.

Le Quéré, C., Raupach, M. R., Canadell, J. G., Marland, G., Bopp, L., Ciais, P., Conway, T. J., Doney, S. C., Feely, R. A., Foster, P., Friedlingstein, P., Gurney, K., Houghton, R. A., House, J. I., Huntingford, C., Levy, P. E., Lomas, M. R., Majku, J., Metz, N., Ometto, J. P., Peters, G. P., Prentice, I. C., Randerson, J. T., Running, S. W., Sarmiento, J. L., Schuster, U., Sitch, S., Takahashi, T., Viovy, N., van der Werf, G. R., and Woodward, F. I.: Trends in the sources and sinks of carbon dioxide, Nat. Geosci., 2, 831-836, doi:10.1038/ngeo689, 2009.

Lefsky, M. A., Cohen, W. B., Parker, G. G., and Harding, D. J.: Lidar Remote Sensing for Ecosystem Studies, BioScience, 52, 19-30, 2002.

Lefsky, M. A., Harding, D. J., Keller, M., Cohen, W. B., Carabajal, C. C., Del Bom Espirito-Santo, F., Hunter, M. O., and de Oliveira, Raimundo, J.: Estimates of forest canopy height and aboveground biomass using ICESat, Geophys. Res. Lett., 32, L22S02, doi:10.1029/2005GL023971, 2005.

Lewis, S. L., Lopez-Gonzalez, G., Sonké, B., Affum-Baffoe, K., Baker, T. R., Ojo, L. O., Phillips, O. L., Reitsma, J. M., White, L., Comiskey, J. A., Djuikouo-K., M.-N., Ewango, C. E. N., Feldpausch, T. R., Hamilton, A. C., Gloor, M., Hart, T., Hladik, A., Lloyd, J., Lovett, J. C., Makana, J.-R., Malhi, Y., Mbago, F. M., Ndangalasi, H. J., Peacock, J., Peh, K. S.-H., Sheil, D., Sunderland, T., Swaine, M. D., Taplin, J., Taylor, D., Thomas, S. C., Votere, R., and Wöll, H.: Increasing carbon storage in intact African tropical forests, Nature, 457, 1003-1006, doi:10.1038/nature07771, 2009.

Luyssaert, S., Schulze, E.-D., Börner, A., Knohl, A., Hessenmöller, D., Law, B. E., Ciais, P., and Grace, J.: Oldgrowth forests as global carbon sinks, Nature, 455, 213-215, doi:10.1038/nature07276, 2008. 
Malhi, Y., Wood, D., Baker, T. R., Wright, J., Phillips, O. L., Cochrane, T., Meir, P., Chave, J., Almeida, S., Arroyo, L., Higuchi, N., Killeen, T. J., Lauranc, e. S. G., Laurance, W. F., Lewis, S. L., Monteagudo, A., Neill, D. A., Vargas, P. N., Pitman, N. C. A., Quesada, C. A., Salomao, R., Silva, J. N. M., Lezama, A. T., Terborgh, J., Martinez, R. V., and Vinceti, B.: The regional variation of aboveground live biomass in old-growth Amazonian forests, Glob. Change Biol., 12, 1107-1138, doi:10.1111/j.13652486.2006.01120.x, 2006.

Moreira, A., Hajnsek, I., Krieger, G., Papathanassiou, K., Eineder, M., Zan, F. D., Younis, M., and Werner, M.: Tandem-L: Monitoring the Earth's dynamic with INSAR and PoL-INSAR, Proc. of 4th Int. Workshop on Science and Applications of SAR Polarimetry and Polarimetric Interferometry - PolInSAR 2009, 2630 January 2009, Frascati, Italy (ESA SP-668, April 2009), 2009.

Ni-Meister, W., Lee, S., Strahler, A. H., Woodcock, C. E., Schaaf, C., Yao, T., Ranson, K. J., Sun, G., and Blair, J. B.: Assessing general relationships between aboveground biomass and vegetation structure parameters for improved carbon estimate from lidar remote sensing, J. Geophys. Res., 115, G00E11, doi:10.1029/2009JG000936, 2010.

Potter, C., Klooster, S., Huete, A., Genovese, V., Bustamante, M., Guimaraes Ferreira, L., R. C. de Oliveira Jr., and Zepp, R.: Terrestrial carbon sinks in the Brazilian Amazon and Cerrado region predicted from MODIS satellite data and ecosystem modeling, Biogeosciences, 6, 937-945, doi:10.5194/bg-6-937-2009, 2009.

Rüger, N., Williams-Linera, G., Kissling, W., and Huth, A.: LongTerm Impacts of Fuelwood Extraction on a Tropical Montane Cloud Forest, Ecosystems, 11, 868-881, 2008.

Saatchi, S. S., Houghton, R. A., Alvalá, R. C. D. S., Soares, J. V., and Yu, Y.: Distribution of aboveground live biomass in the Amazon basin, Glob. Change Biol., 13, 816-837, doi:10.1111/j.1365-2486.2007.01323.x, 2007.
Sabine, C. L., Heimann, M., Artaxo, P., Bakker, D. C. E., Arthur, C.-T., Field, C. B., Gruber, N., Le Quéré, C., Prinn, R. G., Richey, J. E., Lankao, P. R., Sathaye, J. A., and Valentini, R.: Current status and past trends of the global carbon cycle, in: The global carbon cycle: integrating humans, climate, and the natural world, edited by Field, C. B. and Raupach, M. R., pp. 17-44, Island Press, Washington, Covelo, London, 2004.

Schlensog, M.: Experimentelle Untersuchungen des Lichtklimas in Urwaldparzellen Nordborneos, no. 117 in Göttinger Beiträge zur Land- und Forstwirtschaft in den Tropen und Subtropen, Goltze, Göttingen, 1997.

Slik, J. W. F., Raes, N., Aiba, S.-I., Brearley, F. Q., Cannon, C. H., Meijaard, E., Nagamasu, H., Nilus, R., Paoli, G., Poulsen, A. D., Sheil, D., Suzuki, E., van Valkenburg, J. L. C. H., Webb, C. O., Wilkie, P., and Wulffraat, S.: Environmental correlates for tropical tree diversity and distribution patterns in Borneo, Diversity and Distributions, 15, 523-532, 2009.

Slik, J. W. F., Aiba, S.-I., Brearley, F. Q., Cannon, C. H., Forshed, O., Kitayama, K., Nagamasu, H., Nilus, R., Payne, J., Paoli, G., Poulsen, A. D., Raes, N., Sheil, D., Sidiyasa, K., Suzuki, E., and van Valkenburg, J. L. C. H.: Environmental correlates of tree biomass, basal area, wood specific gravity and stem density gradients in Borneo's tropical forests, Global Ecology and Biogeography, 19, 50-60, doi:10.1111/j.1466-8238.2009.00489.x, 2010.

Turner, D. P., Cohen, W. B., Kennedy, R. E., Fassnacht, K. S., and Briggs, J. M.: Relationships between Leaf Area Index and Landsat TM Spectral Vegetation Indices across Three Temperate Zone Sites, Remote Sens. Environ., 70, 52-68, doi:10.1016/ S0034-4257(99)00057-7, 1999.

Yamakura, T., Kanzaki, M., Itoh, A., Ohkubo, T., Ogino, K., K., E. C. O., Lee, H. S., and Ashton, P. S.: Forest structure of a tropical rain forest at Lambir, Sarawak with special reference to the dependency of its physionomic dimensions on topography, Tropics, 6, 1-8, 1996.

Zianis, D. and Mencuccini, M.: On simplifying allometric analyses of forest biomass, Forest Ecol. Manage., 187, 311-332, doi:10. 1016/j.foreco.2003.07.007, 2004. 